\title{
AGE STRUCTURE OF PATIENTS WITH STROKE
}

\author{
Shiraliyeva R.K., Aliyev R.R.*, Sadikhova Z.M., Hasanov R.L., Mammadova M.N., Guliyeva A.I. \\ Azerbaijan State Advanced Training Institute forDoctrs, named after A.Aliyev, department of neuro- \\ logy, Baku, Azerbaijan
}

The ame of this study was exploring age as risk factor for stroke among 173 stroke cases which registered during 3 years (01.01.200731.12.2009) in Siyazan region of Azerbaijan. Mean age of stroke cases during investigated years was 65.2 \pm 0.9 . Males had stroke at a younger age $-62.2 \pm 1.3$ than females - 68.2 $\pm 1.2(p<0.001)$. Patients residing in rural areas had stroke at older age than urban population, which was at a statistically significant level. Most of the stroke patients fell into the age groups of 50-59 and 70-79. In first age group men, in second women. Mean age for ischaemic and hemorrhagic stroke cases was $65.8 \pm 0.9$ and 57.6 \pm 3.4 , respectively.

Keywords: stroke, age, risk factor.

Stroke is the second most common cause of death and a frequent cause of adult disability worldwide $[1,2]$. There are some countries in which the mortality rates of stroke are particularly high, even in more recent years. This includes Azerbaijan, also [3].

Age is the one of the most important non-modifiable risk factor for stroke, with at least a doubling of stroke risk in each decade over age 55 [4]. Some risk factors of stroke are acquired at a younger age (eg, smoking) and thus age can be considered a marker for the duration of exposure to a risk factor, whereas other risk factors tend to become more prevalent with advancing age (eg, hypertension and diabetes) [4]. Men in the United States aged 55 to 64 years were 3 times more likely than men aged 45 to 54 years to have experienced a stroke [5]. The results of Stroke register in Russia showed that, incidence of stroke increased in 30-39 age groups from $0.15 \%$, to $27.7 \%$ in age groups $>70$ [6]. Instead of predicting reduction of incidence in future 20 years, in the end of this period due to population aging the number of patient with stroke will increase $11 \%$ [6]. The aim of our study was exploring age structure in patients with stroke.

Materials and method. We stadied 173 stroke cases which registered in Siyazan region of Azerbaijan using Stroke Registry program durabout $35 \%$ in some developed European countries

ing 3 years (01.01.2007-31.12.2009). Results with CI of $95-99.9 \%(p<0.05-0.001)$ were considered statistically significant [7]. Calculations were performed in Microsoft Excel spreadsheet.

Results. From 173 stroke cases 85 comprised of males $(49.1 \pm 3.8 \%)$ and 88 of females $(50.9 \pm 3.8 \%)$. Age interval of patients was 25-91. Average ages of stroke patients are presented in Table 1.

As seen from the Table 1, average ages of stroke cases for the study period did not demonstrate statistically significant differences. Mean age of stroke cases during investigated years was $65.2 \pm 0.9$.

During the study period, men had stroke at a younger age than women (Table 2), with the difference of $9.7 \%$. Patients residing in rural areas had stroke at elder age than urban population, which was at a statistically significant level.

Average age of stroke patients

Table 1 in Siyazan region (2007-2009)

\begin{tabular}{|l|l|l|l|l|}
\hline & \multicolumn{4}{|c|}{ Year } \\
\cline { 2 - 5 } & 2007 & 2008 & 2009 & $2007-2009$ \\
\hline $\begin{array}{l}\text { Number of } \\
\text { cases (n) }\end{array}$ & 52 & 55 & 66 & 173 \\
\hline Average age & $\begin{array}{l}64.8 \pm 1.5 \\
(42-90)\end{array}$ & $\begin{array}{l}64.1 \pm 1.8 \\
(25-88)\end{array}$ & $\begin{array}{l}66.5 \pm 1.4 \\
(43-91)\end{array}$ & $\begin{array}{l}65.2 \pm 0.9 \\
(25-91)\end{array}$ \\
\hline
\end{tabular}

Note: $p>0.05$; in comparison with each other.

Table 2 Average age characteristics (by gender, residence, and age group) of stroke patients in Siyazan region (2007-2009)

\begin{tabular}{|l|l|l|l|l|l|l|}
\hline & Male & Female & Urban & Rural & Old & Young \\
\hline $\begin{array}{l}\text { Number of } \\
\text { cases (n) }\end{array}$ & 85 & 88 & 122 & 51 & 166 & 7 \\
\hline Mean age & $\begin{array}{l}62.2 \pm 1.3 \\
(25-85)\end{array}$ & $\begin{array}{l}68.2 \pm 1.2 \\
(26-91)\end{array}$ & $\begin{array}{l}64.1 \pm 1.1 \\
(25-91)\end{array}$ & $\begin{array}{l}68.1 \pm 1.4 \\
(47-90)\end{array}$ & $\begin{array}{l}66.5 \pm 0.8 \\
(47-91)\end{array}$ & $\begin{array}{l}35.6 \pm 3.6 \\
(25-44)\end{array}$ \\
\cline { 2 - 7 } & \multicolumn{2}{|c|}{$\mathrm{p}<0.001$} & \multicolumn{2}{|c|}{$\mathrm{p}<0.05$} & $\mathrm{p}<0.001$ \\
\hline
\end{tabular}

*e-mail: rahim_aliyev@mail.ru 
Average age of patients who treated at home was higher in comparison with that receiving inpatient treatment (Table 3 ). Average ages of lethal and non-lethal stroke cases did not demonstrate a statistically significant difference. Study results show that patients experience hemorrhagic stroke at a younger age than ischemic stroke.

Table 3

\section{Average age characteristics (by treatment facility, outcome, and clinical form of stroke)} of stroke patients in Siyazan region (2007-2009)

\begin{tabular}{|l|l|l|l|l|l|l|}
\hline & $\begin{array}{l}\text { In-patient } \\
\text { treatment }\end{array}$ & $\begin{array}{l}\text { Treated at } \\
\text { home }\end{array}$ & Survivals & Deaths & $\begin{array}{l}\text { Ischemic } \\
\text { stroke }\end{array}$ & $\begin{array}{l}\text { Hemorrhagic } \\
\text { stroke }\end{array}$ \\
\hline $\begin{array}{l}\text { Number of } \\
\text { cases (n) }\end{array}$ & 62 & 111 & 118 & 55 & 133 & 22 \\
\hline Average age & $\begin{array}{l}62.1 \pm 1.5 \\
(25-81)\end{array}$ & $\begin{array}{l}67.0 \pm 1.1 \\
(25-91)\end{array}$ & $\begin{array}{l}64.2 \pm 1.0 \\
(25-82)\end{array}$ & $\begin{array}{l}67.5 \pm 1.9 \\
(25-91)\end{array}$ & $\begin{array}{l}65.8 \pm 0.9 \\
(42-86)\end{array}$ & $\begin{array}{l}57.6 \pm 3.4 \\
(25-75)\end{array}$ \\
\hline & \multicolumn{2}{|c|}{$\mathrm{p}<0.05$} & \multicolumn{2}{|c|}{$\mathrm{p}>0.05$} & \multicolumn{2}{c|}{$\mathrm{p}<0.001$} \\
\hline
\end{tabular}

Among patients with stroke, 7 were young $57.14 \pm 18.7 \%$ of males ( 4 cases). From elderly, individuals up to 45 years $(4.0 \pm 1.5 \%)$ and $166 \quad 48.8 \pm 3.9 \%$ were males (81 cases) and $51.2 \pm 3.9 \%$ elderly $(96.0 \pm 1.5 \%)$. From younger group, were females (85 cases). Average age was 35.6 $42.86 \pm 18.7 \%$ consisted of females ( 3 cases) and among young patients and 66.5 among elderly.

Percentage of stroke cases by age and gender (2007-2009)

Table 4

\begin{tabular}{|c|c|c|c|}
\hline \multicolumn{2}{|c|}{ Age group } & $\begin{array}{c}\text { Absolute } \\
\text { number }\end{array}$ & Weight \pm m; \% \\
\hline \multirow{3}{*}{$20-29$} & Total & 3 & $1.7 \pm 1.0$ \\
\cline { 2 - 4 } & M & 2 & $1.16 \pm 0.8$ \\
\cline { 2 - 4 } & F & 1 & $0.58 \pm 0.58$ \\
\hline $30-39$ & Total & 0 & 0 \\
\hline $40-49$ & Total & 12 & $6.9 \pm 1.9$ \\
\cline { 2 - 4 } & M & 8 & $4.6 \pm 1.6$ \\
\cline { 2 - 4 } & F & 4 & $2.3 \pm 1.1$ \\
\hline $50-59$ & Total & 45 & $26.0 \pm 3.3^{* * *}$ \\
\cline { 2 - 4 } & M & 30 & $17.3 \pm 2.9$ \\
\cline { 2 - 4 } & F & 15 & $8.7 \pm 2.1$ \\
\hline $60-69$ & Total & 37 & $21.4 \pm 3.1^{*}$ \\
\cline { 2 - 4 } & M & 17 & $9.8 \pm 2.3$ \\
\cline { 2 - 4 } & F & 20 & $11.6 \pm 2.4$ \\
\hline $70-79$ & Total & 63 & $36.4 \pm 3.7^{* *}$ \\
\cline { 2 - 4 } & M & 26 & $15.0 \pm 2.7$ \\
\cline { 2 - 4 } & F & 37 & $21.4 \pm 3.1$ \\
\hline $80-89$ & Total & 11 & $6.4 \pm 1.9^{* * *}$ \\
\cline { 2 - 4 } & M & 3 & $1.73 \pm 1,0$ \\
\cline { 2 - 4 } & F & 8 & $4.62 \pm 1.6$ \\
\hline $90<$ & Total & 2 & $1.7 \pm 1.0^{* *}$ \\
\hline & M & 0 & 0 \\
\hline & F & 2 & $1.7 \pm 1.0$ \\
\hline
\end{tabular}

Note: ${ }^{*} \mathrm{p}>0.05, * * \mathrm{p}<0.05, * * * \mathrm{p}<0.0001 ; *$ - difference in comparison with previous age group.

During the period of study, most of the stroke stroke more in age group 50-59, and females in patients fell into the age groups of 50-59 and 7079 (Table 4).

age group 70-79, than other age groups, whereas, in other age groups no statistically significant

As seen from Table 4, males experienced differences were identified between males and 
females $(\mathrm{p}<0.05)$. No stroke cases were reported for the age group of 30-39.

Mean ages for ischemic and hemorrhagic stroke cases were $65.8 \pm 0.9$ and $56.7 \pm 3.4$, respectively. As seen, hemorrhagic strokes occured at younger ages in comparison with ischemic strokes.

Among ischemic strokes 3 patients $(2.3 \pm 1.3 \%)$ were young individuals up to 45 years and 130 $(97.7 \pm 1.3 \%)$ were elderly. Among hemorragic strokes 4 patients $(15.4 \pm 7.1 \%)$ were young and $22(84.6 \pm 7.1 \%)$ were elderly.

Discussion. We compare age factor in our patients with other studies. Mean age of stroke cases was $65.2 \pm 0.9$, which is comparable to results obtained in other studies, such as the ones conducted in Barcelona, Spain (66.0) [8], Ege, Turkey (62.3 \pm 12.0$)$ [9], Nablus, Palestine (69.09 \pm 10.9$)$ [10]. During the study conducted in United Kingdom (Southern London), it was identified that average age of stroke patients was 71.1 , which is higher than our finding [11]. In the other study in UK, which covered 1999-2008 years, the average age at first stroke was 77 years in women and 71 years in men [12].

In a 3-year randomized study conducted in Kazan, average age of stroke cases with the onset of disease in May and treated at home, was 74.3, with 68.5 and 75.5 among males and females, respectively [13]. Findings of the study conducted in Ufa, Russia, using Stroke Registry approach, demonstrated average age of $66.86 \pm 11.79$ among males and $72.17 \pm 11.5$ among females, which shows no statistically significant difference when compared to the results of this study [14].

\section{REFERENCES}

1. Johnston SC, Mendis S, Mathers CD. Global variation in stroke burden and mortality: estimates from monitoring, surveillance, and modelling. Lancet Neurol 2009; 8:345-54 2. Rothwell PM. The high cost of not funding stroke research: a comparison with heart disease and cancer. Lancet 2001; 357:1612-6

3. Thrift A.G., Cadilhac D.A., Thayabaranathan T., Howard G. et al. Global stroke statistics // International Journal of Stroke, Vol 9, January 2014, 6-18

4. American Academy of Neurology. Continuum. Acute stroke management. April 2003, Vol.9, №2, p. 53-68

5. Towfighi A., Saver J., Liemeskind D., et al. Does overall atherosclerotic burden contribute to late midlife acceleration of stroke in men? // Stroke 2007; 38:533 (abstr)

6. Gusev E.I., Skvortsova V.I., Stakhovskaya L.V. Epidemiologiya insulta $\mathrm{v}$ Rossii // Zhurnal nevrologii i
As we show at the top, most of the stroke patients fell into the age groups of 50-59 for men and 70-79 for women. Among the first age group prevailed men with arterial hypertension, coronary heart diseases (CHD) and diabetis mellitus, among the second group women prevailed with similarly risk faktors.

In one study, which conducted in Azerbaijan among 32 patients with ichaemic stroke under 45 years old, has shown that in young people rheumatic vasculitis, heart, kidney, blood diseases and family hypercholesterolemia are the most occuring risk factors of stroke [15].

African americans, American indians/Alaska natives, Asians and Hispanic Americans die from stroke in early ages in comparison with Caucasians [16, 17, 18].

In 50-59 age group treatment of atrial fibrilation with varfarin reduced stroke risk for $68 \%$, in 60-69 age group treaetment of atrial fibrilation with aspirin redusing stroke risk for $21 \%$ [11].

In middle-aged and elderly men increasing of blood preasure as a response under stress situations caused raising risk of tromboembolic isceamic stroke [19].

As we see from the most studies aging increases risk of stroke with an increased frequency of other risk factors.

Conclusion. In this study we discussed age factor for stroke, and we find that, some age groups needs in preventive treatment of stroke. It could reduce incidence of stroke in region.

Conflict of interest. The authors declare no financial or other conflict of interests.

psikhiatrii imeni S.S. Korsakova, (prilojezhenie "Insult"). 2003, Vip. 8. s. 4-9

7. Vlasov V.V. Epidemiologiya: Uchebnoe posobie dlya vuzov. Moskva: Izdatelskaya gruppa "GEOTAR-Media", 2006, $462 \mathrm{~s}$ 8. Marti-Vialta J.L., Arboix A. The Barcelona stroke registry // European Neurology, 1999; Vol. 41. №3. p. 135-142 9. Kumral E., Ozkaya B., Sagduyu A. The Ege Stroke Registry: A hospital-based study in the Aegen region, Izmir, Turkey // Cerebrovascular Diseases, 1998. Vol. 8. №5. p. 278-288

10. Sweileh W.M., Sawalha A.F., Al-Aqad M. Sana, et al. The Epidemiology of Stroke in Northern Palestine: A OneYear, Hospital-Based Study // Journal of stroke and cerebrovascular disease, 2008; 17(6): p. 406-411

11. Wolfe C.D.A. The impact of stroke // British Medical Bulletin, 2000. Vol. 56. №2. p. 275-286 
12. Lee S, Shafe ACE, Cowie MR. UK stroke incidence, mortality and cardiovascular risk management 1999e2008: timetrend analysis from the General Practice Research Database // BMJ Open 2011;1:e000269. doi:10.1136/bmjopen-2011-000269 13. Khaertdinov R.F., Ismagilov M.F., Galiullin A.N. Analiz mesyachnoy letalnosti pri ostrich narusheniyax mozgovogo krovoobrasheniya sredi negospitalizirovannikh bolnikh // Nevrologicheskiy vestnik, 2004, T. XXXVI, vip. 3-4, s. 23-25

14. Kachemaeva O.V., Borisova N.A. Epidemiologicheskaya kharakteristika insulta $\mathrm{v}$ g. Ufe podannim registra // Nevrologicheskiy vestnik, 2007, T. XXXIX, vip. 1, s. 45-48 15. Sultanova F.A., Khalilova D.M., Alekperova S.P. K voprosu etiologii ishemicheskikh insultov $\mathrm{v}$ molodom vozraste / Z.Salayevanin 80 illik yubileyine hesr olunmush elmi konfransin megaleler toplusu, 2003. s. 151-154
16. Casper M., Barnett E., Williams G., et al. Atlas of stroke mortality: racial, ethnic, and geographic disparities in the United States. Atlanta, GA: US Department of Health and Human Services, CDC; January 2003. http://www.cdc.gov/dhdsp/library/maps/strokeatlas/index.htm 17. Rosamond W., Flegal K., Friday G., et al. Heart disease and stroke statistics - 2007 update: a report from the American Heart Association Statistics Committee and Stroke Statistics Subcommittee. Circulation, 2007, v.115, e69-e171 18. Stansbury J., Jia H., Williams L., Vogel W., et al. Ethnic disparities in stroke: epidemiology, acute care, and post acute outcomes // Stroke, 2005, v.36, p.374-387

19. May M., McCarron P., Stansfeld S., et al. Does psychological distress predict the risk of ischemic stroke and transient ischemic attack? The Caerphilly Study // Stroke, 2002, v.33, p.7-12

\title{
XÜLASZ
}

\section{İNSULTLU XəSTЭLӘRIN YAȘ STRUKTURU}

\author{
Şirəliyeva R.K., Oliyev R.R., Sadıxova Z.M., Həsənov R.L., Məmmədova M.N., Quliyeva A.İ. \\ O. Oliyev adına Azarbaycan Dövlat Həkimlari Təkmillaşdirmə Institutu, sinir xastaliklari kafedrası, \\ Bakl, Azorbaycan
}

Təqdim edilmiş məqalənin məqsədi Siyəzən rayonunda 3il (01.01.2007-31.12.2009) ərzində qeydiyyata alınmış 173 xəsədə yaşın risk amili kimi rolunu öyrənmək olmuşdur. Tədqiqat illərində xəstələrin orta yaşı $65,2 \pm 0,9$ olmuşdur. Qadınlarla $(68,2 \pm 1,2)$ müqayisədə kişilər $(62,2 \pm 1,3)$ insultla daha cavan yaşlarda xəstələnirdilər $(\mathrm{p}<0,001)$. Kənd sakinləri insultla şəhər sakinləri ilə müqayisədə daha yaşlı dövrdə xəstələnmişdirlər. Xəstələrin çoxu insultla 50-59 və 70-79 yaş dövründə xəstələnirdilər. İşemik və hemorragik insult üçün orta yaş həddi müvafiq olaraq $65,8 \pm 0,9$ və $57,6 \pm 3,4$ olmuşdur.

Açar sözlər: insult, yaş, risk amili.

\section{PЕЗЮМЕ}

\section{ВОЗРАСТНАЯ СТРУКТУРА БОЛЬНЫХ С ИНСУЛЬТОМ}

\author{
Ширалиева Р.К., Алиев Р.Р., Садыхова 3.М., Гасанов Р.Л., Мамедова М.Н., Гулиева А.И. \\ Азербайджанский Государственньй Институт Усовершенствования Врачей им. А.Алиева, \\ кафедра нервных болезней, Баку, Азербайджан
}

Целью данной работы явилось изучение возраста больных, в качестве фактора риска среди 173 больных инсультом, которые зарегистрировались в течение 3 лет (01.01.2007-31.12.2009) в Сиязаньском районе Республики Азербайджан. Средний возраст больных инсультом в исследуемые годы составил $65,2 \pm 0,9$. Мужчины болели инсультом в более молодом возрасте - $62,2 \pm 1,3$ по сравнение с женщинами - 68,2 $\pm 1,2$ ( $<<0,001)$. Пациенты из сельских населенных пунктов болели инсультом в более пожилом возрасте по сравнение с городскими пациентами. Большинство больных страдали инсультом в возрастных группах 50-59 и 70-79. В первой возрастной группе мужчины, во второй женщины. Средний возраст для ишемического и геморрагического инсульта составили соответственно $65,8 \pm 0,9$ и $57,6 \pm 3,4$. Ключевые слова: инсульт, возраст, фактор риска.

Redaksiyaya daxil olub: 19.10.2015

Çapa tövsiya olunub: 04.11.2015

Rayçi: t.ü.f.d. Hasanov X.I. 